\title{
A Lysosome-Targetable Fluorescence Probe Based on L-Cysteine-Polyamine-Morpholine-Modified Quantum Dots for Imaging in Living Cells
}

This article was published in the following Dove Press journal: International Journal of Nanomedicine

\section{Zhi-Qiang Zhang \\ Wen-jing Yao \\ Lu-Lu Qiao \\ Xiaojing Yang \\ Jiahua Shi \\ Mei-Xia Zhao}

Key Laboratory of Natural Medicine and Immune Engineering, Henan University, Kaifeng 475004, People's Republic of China
Correspondence: Mei-Xia Zhao

Key Laboratory of Natural Medicine and Immune Engineering, Henan University, Jinming Road, Kaifeng 475004, People's Republic of China

Email zhaomeixia20II@henu.edu.cn
Purpose: Quantum dots (QDs) are used as fluorescent probes due to their high fluorescence intensity, longevity of fluorescence, strong light-resistant bleaching ability and high light stability. Therefore, we explore a more precise probe that can target an organelle.

Methods: In the current study, a new class of fluorescence probes were developed using QDs capped with 4 different L-cysteine-polyamine-morpholine linked by mercapto groups. Ligands were characterised by Electrospray ionization mass spectrometry (ESI-MS), H-Nuclear Magnetic Resonance $\left({ }^{1} \mathrm{H}\right.$ NMR) spectroscopy, and ${ }^{13} \mathrm{C}$ NMR spectroscopy. Modified QDs were characterized by Transmission Electron Microscope (TEM), Ultraviolet and visible spectrophotometry (UV-Vis), and fluorescence microscopy. And the biological activity of modified QDs was explored by using MTT assay with HeLa, SMMC7721 and HepG2 cells. The fluorescence imaging of modified QDs was obtained by confocal laser scanning fluorescence microscopy (CLSM).

Results: Synthesized QDs ranged between 4 to $5 \mathrm{~nm}$ and had strong optical emission properties. UV-Vis and fluorescence spectra demonstrated that the cysteine-polyaminemorpholine were successfully incorporated into QD nanoparticles. The MTT results demonstrated that modified QDs had lesser cytotoxicity when compared to unmodified QDs. In addition, modified QDs had strong fluorescence intensity in HeLa cells and targeted lysosomes of HeLa cells.

Conclusion: This study demonstrates the modified QDs efficiently entered cells and could be used as a potential lysosome-targeting fluorescent probe.

Keywords: quantum dots, fluorescence probe, lysosome-targetable, cells imaging

\section{Introduction}

Quantum dots (QDs) have range of applications as nano-fluorescent probes and antitumor drug carriers, due to their unique optical properties and electronic structure. ${ }^{1-6}$ Although QDs have strong fluorescence intensity, long fluorescence lifetime and high light stability, QDs generally have poor water solubility, high toxicity and poor cell targeting ability. ${ }^{7-13}$ It is well known that hydrophobic QDs can be engineered to have great water solubility through surface-exchange of hydrophobic surfactant molecules for hydrophilic ligands. ${ }^{14-18}$ In addition, the cytotoxicity of QDs can be reduced and targeting of tumor cells can be enhanced through modification of QD surfaces using biomolecules. ${ }^{19-23}$ Therefore, when interfaced with biological molecules including proteins, peptides, carbohydrates or DNA, the resulting QD-biocomposites have widespread applicability in areas ranging from 
cellular fluorescence imaging to in vivo fluorescence imaging. ${ }^{24-30}$ However, following surface modification of QDs, it is important to retain its fundamental properties, such as uniform dispersion and to ensure that functional groups remain available for biological applications. ${ }^{31-35}$ As a result, development of targetable fluorescent probe QDs with fundamental properties of bio-molecules.

Polyamines are widely distributed in the body, and are associated with cell proliferation and differentiation process. ${ }^{36-40}$ In recent years, polyamine derivatives have attracted increasing attention due to their ability to enhance the selectivity and bioactivity of compounds. ${ }^{41-46}$ Protein primary structure consists of amino acids linked by peptide bonds. Because amino acids are generally water-soluble and inexpensive, they have been used as capping agents for QDs. ${ }^{47-51}$ Amino acid contain an amino and carboxyl group, therefore they can be directly linked to the surface of QDs and other drugs with the antitumor activity or targetable groups. ${ }^{52-57}$

In this paper, we synthesized a new class of modified QDs with small size, good water solubility, disperse uniformly and strong optical emission properties. In such models, four types of amino acid-polyamine-morpholine derivatives were used and the bio-activities of modified QDs were greatly improved. Since the polyamine or its derivatives are able to mimic the environment of the second coordination sphere in the active site of the corresponding enzyme. The modified QDs were characterized by transmission electron micrographs (TEM), UV-Visible Spectrophotometer (UV-Vis), and fluorescence spectrophotometer. Biological activity of modified QDs was explored using the MTT assay with HeLa, SMMC-7721 and HepG2 cells. Results demonstrated that modified QDs were less toxic to these cells. Fluorescence imaging of modified QDs with confocal laser scanning fluorescence microscopy (CLSM) demonstrated strong fluorescence intensity in targeted lysosomes of HeLa cells.

\section{Materials and Methods Materials}

All reagents were purchased from commercial suppliers and used without further purification. Solvents were purified by standard methods prior to use. Cervical cancer cells (HeLa), human hepatoma cells (SMMC-7721) and human hepatoma cells (HepG2) were obtained from the Shanghai Cell Bank of the Chinese Academy of Sciences.

${ }^{1} \mathrm{H}$ NMR spectra were recorded on a Bruker AV-400 spectrometers. ESI-MS spectra were performed on a Thermo LCQ-DECA-XP spectrometer. UV-Vis spectra were monitored using a Varian Cary 300 UV-Vis spectrophotometer. Fluorescence spectra were measured using a Varian Cary Eclipse fluorescence spectrophotometer (American, Agilent, Co.). Confocal microscopy images were obtained using a confocal laser scanning fluorescence microscope (Leica SP8, Germany). The cell fluorescence intensity was measured using a FACSCalibur flow cytometer (Becton Dickinson \& Co., Franklin Lakes, NJ).

\section{Synthesis of L-Cysteine-2-Amino- 3-Mercapto-N-(3- Morpholinopropyl) propanamide (L-Cys-MPA) (Scheme I)}

A $250 \mathrm{~mL}$ round bottomed flask equipped with a magnetic stirring bar was charged with Boc-Cys(trt)-OH (2.0 g, 3.5 $\mathrm{mmol})(\mathbf{1})$ dissolved in $100 \mathrm{~mL}$ acetonitrile and $0.59 \mathrm{~g} \mathrm{(3.5}$

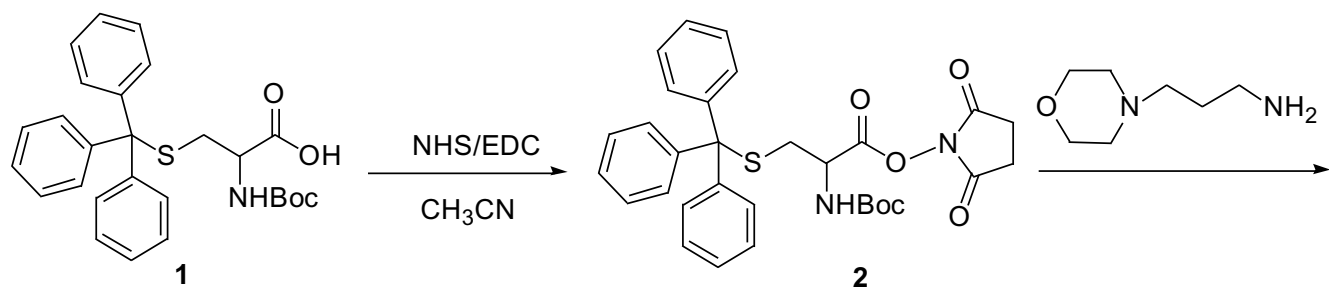

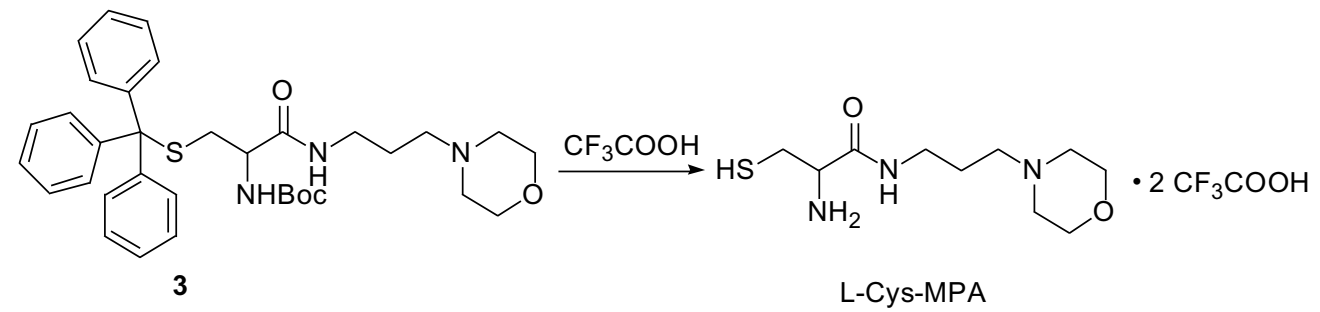

Scheme I Schematic illustration of the formation of the L-Cys-MPA. 
mmol) NHS. Next, EDC (0.89 g, $3.5 \mathrm{mmol})$ was added dropwise and stirred at $0^{\circ} \mathrm{C}$ for $2 \mathrm{hrs}$. Then the reaction mixture was stirred at room temperature overnight. After completion, the precipitate was filtered, extracted with chloroform and vacuum dried to produce a slightly yellow solid.

$\mathrm{N}$-aminopropylmorpholine $(0.5 \mathrm{~g}, 3.5 \mathrm{mmol})$, compound 2, and $\mathrm{NaHCO}_{3}(0.35 \mathrm{~g}, 4.2 \mathrm{mmol})$ were placed in a $100 \mathrm{~mL}$ round-bottomed flask with a magnetic stirrer, and stirred at $60^{\circ} \mathrm{C}$ for $12 \mathrm{hrs}$. Next, the reaction mixture was evaporated to dryness under reduced pressure and extracted with chloroform. After vacuum drying, the solid was purified by silica gel column chromatography using a $\mathrm{CH}_{2} \mathrm{Cl}_{2}-\mathrm{CH}_{3} \mathrm{OH}(\mathrm{v}: \mathrm{v}=20: 1)$ mixture as the eluent to obtain the yellow grease compound $\mathbf{3}$.

Compound 3 was dissolved in $10 \mathrm{~mL} \mathrm{CH}_{2} \mathrm{Cl}_{2}$ in a $50 \mathrm{~mL}$ three-necked flask, and then trifluoroacetic acid (TFA) $(9.5 \mathrm{~mL})$ and triethyl silicane $0.5 \mathrm{~mL}$ were injected sequentially under nitrogen protection. The resulting solution was stirred at $25^{\circ} \mathrm{C}$ for $6 \mathrm{hrs}$. After completion, the reaction mixture was evaporated to dryness under reduced pressure, and the residues were extracted with dichloromethane and distilled water. Removal of the solvent from the aqueous phase resulted in a solid compound 2-amino-3-mercapto$\mathrm{N}$-(3-morpholinopropyl) propanamide (L-Cys-MPA).
L-Cys-MPA, yield: 75\%; ${ }^{1} \mathrm{H}$ NMR $\left(300 \mathrm{MHz}, \mathrm{D}_{2} \mathrm{O}\right) \delta$ $3.98(\mathrm{dd}, \mathrm{J}=7.4,4.5 \mathrm{~Hz}, 2 \mathrm{H}), 3.92(\mathrm{~d}, \mathrm{~J}=1.5 \mathrm{~Hz}, 1 \mathrm{H})$, 3.71-3.55 (m, 2H), 3.41-3.30 (m, 2H), $3.20(\mathrm{q}, \mathrm{J}=7.2$ $\mathrm{Hz}, 2 \mathrm{H}), 3.04$ (dt, J=12.3, $4.5 \mathrm{~Hz}, 4 \mathrm{H}), 2.88$ (dd, J=5.9, $2.1 \mathrm{~Hz}, 2 \mathrm{H}), 1.90-1.76(\mathrm{~m}, 2 \mathrm{H}) ;{ }^{13} \mathrm{C}$ NMR $\left(75 \mathrm{MHz}, \mathrm{D}_{2} \mathrm{O}\right)$ $\delta 168.03,163.35,162.87,162.40,161.93,121.97,118.11$, $114.25,110.39,63.66,54.67,54.42,51.67,51.65,36.38$, 24.62, 22.98; ESI-MS, m/z: $248.09[\mathrm{M}+\mathrm{H}]^{+}$.

\section{Synthesis of L-Cysteine-N'- (3-Morpholinopropyl) Propane-I,3-Diamine (L-Cys-MPPDA), L-Cysteine-N'- (4-Morpholinobutyl) Butane-I,4-Diamine (L-Cys-MBBDA) (Scheme 2)}

A $100 \mathrm{~mL}$ round-bottom flask equipped with a magnetic stirring bar was charged with $\mathrm{N}$-aminopropylmorpholine $(1.4 \mathrm{~g}, 10 \mathrm{mmol})$ dissolved in $50 \mathrm{~mL}$ acetonitrile and $\mathrm{K}_{2}$ $\mathrm{CO}_{3}(2.1 \mathrm{~g}, 15 \mathrm{mmol})$. Then N-(3-Bromopropyl) phthalimide $(2.7 \mathrm{~g}, 10 \mathrm{mmol})$ or $\mathrm{N}$-(4-Bromobutyl) phthalimide (2.8 g, $10 \mathrm{mmol}$ ) was added and stirred at $25^{\circ} \mathrm{C}$ for $12 \mathrm{hrs}$. After completion, the reaction mixture was evaporated to dryness under reduced pressure, and the residues were extracted with dichloromethane and $10 \% \quad \mathrm{Na}_{2} \mathrm{CO}_{3}$. Removal of the solvent in the organic phase resulted in

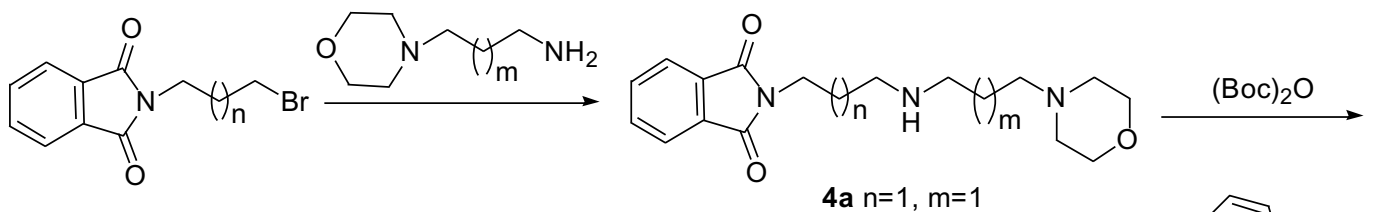

4a $n=1, m=1$

$4 b \mathrm{~b}=2, \mathrm{~m}=2$
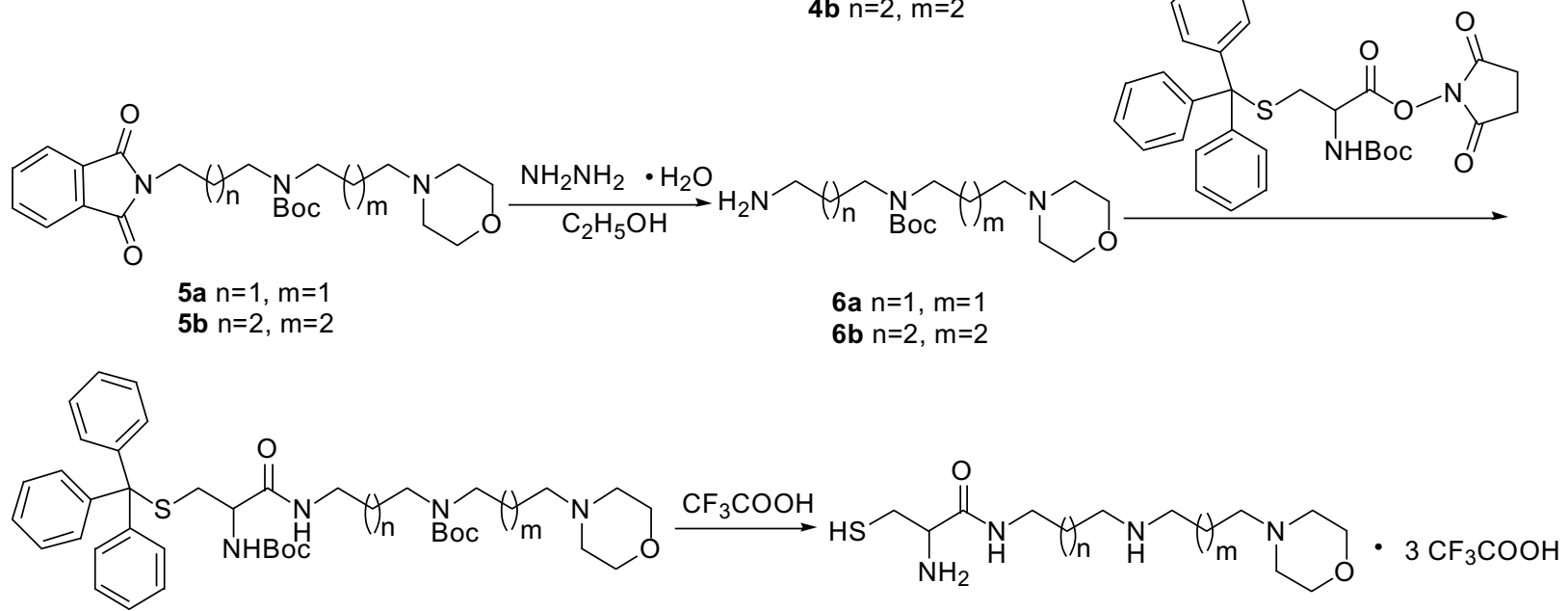

7a $n=1, m=1$

$7 \mathrm{~b} n=2, \mathrm{~m}=2$
L-Cys-MPPDA $n=1, m=1$ L-Cys-MBBDA $n=2, m=2$

Scheme 2 Schematic illustration of the formation of the L-Cys-MPPDA and L-Cys-MBBDA. 
a yellow compound $\mathbf{4 a}$ or $\mathbf{4 b}$. Then compound $\mathbf{4 a}$ or $\mathbf{4 b}$ was dissolved in $50 \mathrm{~mL}$ methyl alcohol and (Boc) $)_{2} \mathrm{O}(3.3 \mathrm{~g}$, $15 \mathrm{mmol}$ ) was added and the solution was stirred at $25^{\circ} \mathrm{C}$ for 12 hrs. After completion, the reaction mixture was evaporated to dryness under reduced pressure. After vacuum drying, the resulting solid was purified on a silica gel column using a $\mathrm{CH}_{2} \mathrm{Cl}_{2}-\mathrm{CH}_{3} \mathrm{OH}(\mathrm{v}: \mathrm{v}=20: 1)$ mixture as the eluent to obtain the grease compound $\mathbf{5 a}$ or $\mathbf{5 b}$. Compound $\mathbf{5 a}$ or $5 \mathbf{b}$ was then dissolved in $50 \mathrm{~mL}$ absolute ethyl alcohol, and hydrazine hydrate $\left(\mathrm{NH}_{2} \mathrm{NH}_{2}\right)(5 \mathrm{~mL})$ was added and stirred for at $25^{\circ} \mathrm{C}$ for $12 \mathrm{hrs}$. The resulting mixture was evaporated to dryness under reduced pressure, and the residues extracted with $\mathrm{CH}_{2} \mathrm{Cl}_{2}$ and $10 \% \mathrm{Na}_{2} \mathrm{CO}_{3}$. Following removal of the solvent, the solid compound $6 \mathbf{a}$ or 6b was produced. Synthesis of $\mathbf{7 a}$ or $\mathbf{7 b}$, L-Cys-MPPDA and L-Cys-MBBDA was completed using a similar method but with compound 3 and L-Cys-MPA.

L-Cys-MPPDA, yield: 76\%; ${ }^{1} \mathrm{H}$ NMR (300 MHz, $\mathrm{D}_{2}$ O) $\delta 4.10(\mathrm{~d}, \mathrm{~J}=3.0 \mathrm{~Hz}, 2 \mathrm{H}), 4.05(\mathrm{~d}, \mathrm{~J}=3.0 \mathrm{~Hz}, 1 \mathrm{H}), 3.78$ $(\mathrm{t}, \mathrm{J}=13.5 \mathrm{~Hz}, 2 \mathrm{H}), 3.50(\mathrm{~d}, \mathrm{~J}=12.0 \mathrm{~Hz}, 2 \mathrm{H}), 3.32$ (dd, $\mathrm{J}=12.1,5.2 \mathrm{~Hz}, 1 \mathrm{H}), 3.27-3.18(\mathrm{~m}, 3 \mathrm{H}), 3.18-3.00(\mathrm{~m}$, 6H), 2.20-2.05 (m, 2H), 1.89 (p, J=7.0 Hz, 2H). ${ }^{13} \mathrm{C}$ NMR $\left(75 \mathrm{MHz}, \mathrm{D}_{2} \mathrm{O}\right) \delta 168.12,63.64,54.41,53.60,51.73$, 45.31, 44.26, 36.41, 25.33, 24.64, 20.32. ESI-MS, m/z: $305.20[\mathrm{M}+\mathrm{H}]^{+}$.

L-Cys-MBBDA, yield: 79\%; ${ }^{1} \mathrm{H}$ NMR (300 MHz, $\mathrm{D}_{2}$ O) $\delta 4.08(\mathrm{~d}, \mathrm{~J}=6.0 \mathrm{~Hz}, 2 \mathrm{H}), 4.04(\mathrm{t}, \mathrm{J}=4.5 \mathrm{~Hz}, 1 \mathrm{H}), 3.74(\mathrm{t}$, $\mathrm{J}=12 \mathrm{~Hz}, 2 \mathrm{H}), 3.45$ (d, J=6.0Hz, 2H), 3.33-3.09 (m, 4H), 3.09-2.94 (m, 6H), 1.83-1.47 (m, 8H). ${ }^{13} \mathrm{C}$ NMR (75 $\left.\mathrm{MHz}, \mathrm{D}_{2} \mathrm{O}\right) \delta 167.73,163.49,163.02,162.55,162.08$, $122.07,118.21,114.35,110.49,63.70,56.22,54.48$, 51.61, 47.09, 46.61, 38.84, 25.37, 24.76, 22.97, 22.59, 20.32. ESI-MS, m/z: $333.29[\mathrm{M}+\mathrm{H}]^{+}$.

\section{Synthesis of L-Cysteine- $N^{\prime}$ -} (3-Aminopropyl)- $\mathrm{N}^{3}$-(3- Morpholinopropyl) propane-I,3-Diamine (L-Cys-AMPDA)

\section{(Scheme 3)}

A $100 \mathrm{~mL}$ round-bottomed flask equipped with a magnetic stirring bar was charged with 6a $(3.0 \mathrm{~g}, 10 \mathrm{mmol})$ dissolved in $50 \mathrm{~mL}$ acetonitrile solution and $\mathrm{K}_{2} \mathrm{CO}_{3}(2.1 \mathrm{~g}, 15 \mathrm{mmol})$. Then, N-(3-Bromopropyl) phthalimide (2.7 g, $10 \mathrm{mmol})$ was added and stirred at $25^{\circ} \mathrm{C}$ for $12 \mathrm{hrs}$. After completion, the reaction mixture was evaporated to dryness under reduced pressure, and the residues extracted with $\mathrm{CH}_{2} \mathrm{Cl}_{2}$ and $10 \%$ $\mathrm{Na}_{2} \mathrm{CO}_{3}$. Removal of the solvent in the organic phase resulted in a yellow greasy compound, termed compound
8. Then the compound $\mathbf{8}$ was dissolved in $50 \mathrm{~mL}$ methyl alcohol solution. (Boc) $)_{2} \mathrm{O}(3.3 \mathrm{~g}, 15 \mathrm{mmol})$ was added and the mixture was stirred at $25^{\circ} \mathrm{C}$ for $12 \mathrm{hrs}$. The resulting reaction mixture was concentrated under vacuum and further purified by silica gel column chromatography to obtain a greasy compound, termed compound 9. Next, the compound 9 was dissolved in $50 \mathrm{~mL}$ ethyl alcohol and the hydrazine hydrate $\left(\mathrm{NH}_{2} \mathrm{NH}_{2}\right)(5 \mathrm{~mL})$ was added. The solution stirred at $25^{\circ} \mathrm{C}$ for $12 \mathrm{hrs}$. After completion, the reaction mixture was evaporated to dryness under reduced pressure, and the residues were extracted with $\mathrm{CH}_{2} \mathrm{Cl}_{2}$ and $10 \% \mathrm{Na}_{2}$ $\mathrm{CO}_{3}$. The organic phases were then dried with $\mathrm{Na}_{2} \mathrm{SO} 4$ under vacuum to yield compound 10. Synthesis of compound 11 and L-Cys-AMPDA can refer to the synthetic method of compound 3 and L-Cys-MPA.

L-Cys-AMPDA, yield: 70\%; ${ }^{1} \mathrm{H}$ NMR (300 MHz, Deuterium Oxide) $\delta 4.18(\mathrm{~d}, \mathrm{~J}=6.0 \mathrm{~Hz}, 2 \mathrm{H}), 4.12(\mathrm{~s}, 1 \mathrm{H})$, $3.83(\mathrm{t}, \mathrm{J}=12.0 \mathrm{~Hz}, 2 \mathrm{H}), 3.56(\mathrm{~d}, \mathrm{~J}=12.0 \mathrm{~Hz}, 2 \mathrm{H}), 3.45-$ $3.22(\mathrm{~m}, 6 \mathrm{H}), 3.22-3.04(\mathrm{~m}, 10 \mathrm{H}), 2.25-2.04(\mathrm{~m}, 4 \mathrm{H})$, $1.96(\mathrm{q}, \mathrm{J}=7.3 \mathrm{~Hz}, 2 \mathrm{H}) .{ }^{13} \mathrm{C} \mathrm{NMR}\left(75 \mathrm{MHz}, \mathrm{D}_{2} \mathrm{O}\right) \delta$ $163.10,162.63,118.18,114.32,63.68,54.45,53.60$, 51.77, 45.32, 44.57, 44.39, 36.46, 29.74, 25.36, 24.67, 22.60, 20.32. ESI-MS, m/z: $364.32[\mathrm{M}+\mathrm{H}]^{+}$.

\section{Synthesis of Water-Soluble Amino Acid-Polyamine-Morpholine-Modified QDs}

QDs $(1 \mathrm{~mL})$ (CdSe or $\mathrm{CdSe} / \mathrm{ZnS}$ or $\mathrm{CdSe} / \mathrm{CdS})$ in $1 \mathrm{~mL}$ of chloroform, amino acid-polyamine-morpholine $(300 \mathrm{mg})$ in $3 \mathrm{~mL}$ triple distilled and water and 10 drops triethanolamine were placed in a bottle, and sonicated for $4 \mathrm{hrs}$. After completion, ethyl acetate was added to precipitate nanocrystal complexes to purify nanocrystals. The solid was filtered and dried under vacuum to obtain the water-soluble amino acid-polyamine-morpholine derivatives modified QDs.

\section{Cell Culture}

Three types of cells (HeLa, SMMC-7721, HepG2) were cultured in RMPI- 1640 medium at $37^{\circ} \mathrm{C}$ under $5 \% \mathrm{CO}_{2}$. These cells were allowed to grow in a monolayer in a tissue culture flask.

\section{Cell Cytotoxicity Test}

Antitumor activity of modified QDs was monitored using a modified MTT method. Briefly, cells were seeded into 96-well plates at $5 \times 10^{4}$ cells per well. After $12 \mathrm{hrs}$, the modified QDs (50, 100, 200, 500 and $1000 \mu \mathrm{g} / \mathrm{mL})$ were 


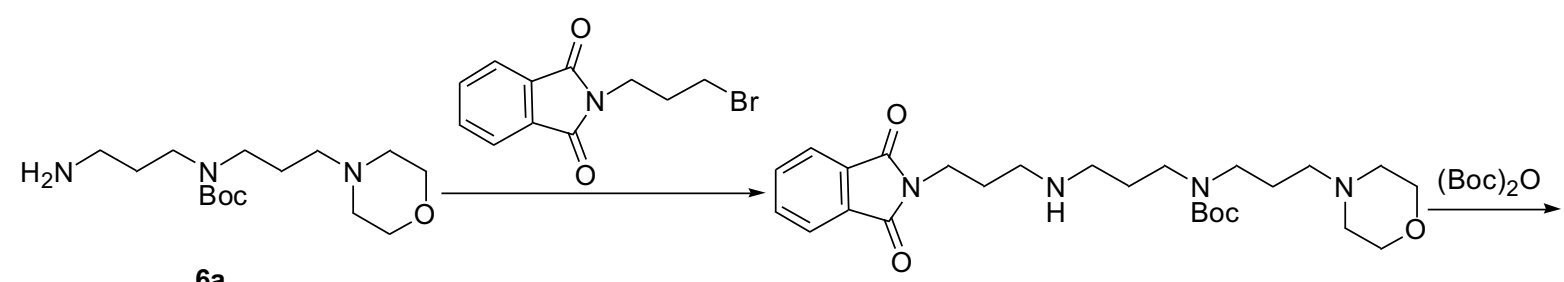

$6 a$

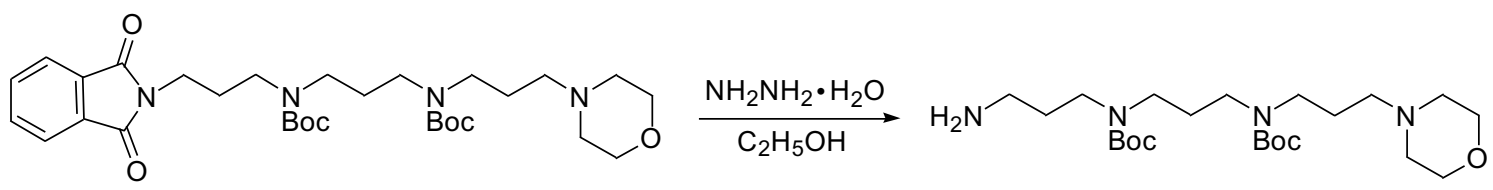

9

10

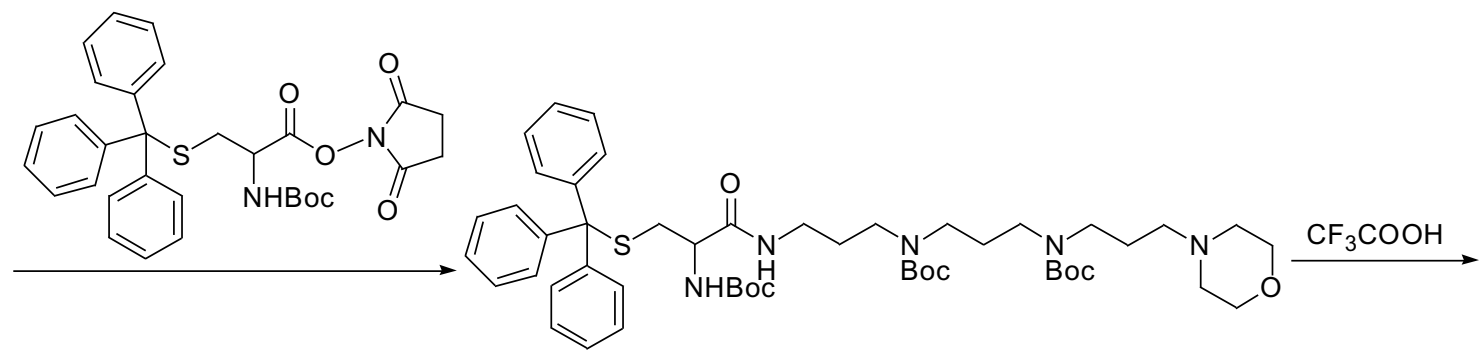

11

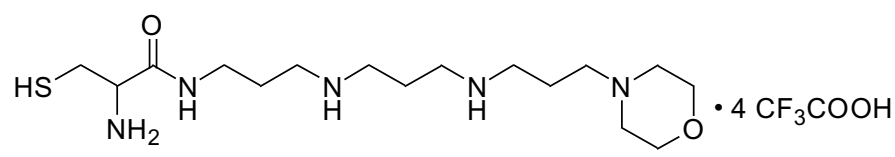

L-Cys-AMPDA

Scheme 3 Schematic illustration of the formation of the L-Cys-AMPDA.

subsequently added and incubated for 48 hrs. Next, $20 \mu \mathrm{L}$ MTT $(2.5 \mathrm{mg} / \mathrm{mL})$ was added to each well and after $4 \mathrm{hrs}$, supernatant was removed and $100 \mu \mathrm{L}$ DMSO was added to each well for 10-15 mins. The absorbance was measured at a wavelength of $570 \mathrm{~nm}$ and the inhibition of cell growth was calculated for each concentration of the samples.

\section{Cellular Uptake of Modified QDs}

HeLa cells were seeded in a $35 \mathrm{~mm}$ diameter utensil containing $15 \mathrm{~mm}$ diameter glass cover-slips, in culture medium containing $10 \% \mathrm{FBS}$ incubated for $24 \mathrm{hrs}$ at $37^{\circ} \mathrm{C}$ and $5 \% \mathrm{CO}_{2}$. The modified QDs were then added at the indicated time points $(1,2,6,12$, and $24 \mathrm{hrs})$. Then, cells were washed twice with PBS buffer, and incubated with Hoechst $33342(10 \mu \mathrm{g} / \mathrm{mL})$ for $30 \mathrm{mins}$ at $37^{\circ} \mathrm{C}$. The cells were washed with PBS, and viewed using a confocal microscope (Leica-SP8) at an excitation wavelength of
$488 \mathrm{~nm}$ and emission wavelength between 580 and $650 \mathrm{~nm}$. Cell nuclei stained with Hoechst 33342 were observed at a wavelength of $405 \mathrm{~nm}$, and emission wavelength between 430 and $480 \mathrm{~nm}$.

\section{Targeted Localization of Modified QDs in Cells}

HeLa cells were seeded in a $35 \mathrm{~mm}$ diameter utensil containing $15 \mathrm{~mm}$ diameter glass cover-slips, in culture medium containing 10\% FBS and incubated for $24 \mathrm{hrs}$ at $37^{\circ} \mathrm{C}$ and $5 \% \mathrm{CO}_{2}$. Then the modified QDs $(200 \mu \mathrm{g} / \mathrm{mL})$ were added to the utensil and incubated for $6 \mathrm{hrs}$. The cells were thoroughly washed with PBS buffer to remove QDs which were not absorbed. Then the cells were incubated for 30 mins at $37^{\circ} \mathrm{C}$ with the green fluorescent probe LysoTracker Green DND-26 (1 $\mu \mathrm{M})$, and then rinsed twice with PBS. The images of the cells were obtained using a fluorescence microscope. The excitation 
wavelength of the QDs was $488 \mathrm{~nm}$, and the emission wavelength was $580-650 \mathrm{~nm}$. The excitation wavelength of LysoTracker green DND-26 was $488 \mathrm{~nm}$. The band path for the marker imaging was between 500 and $560 \mathrm{~nm}$.

\section{Results and Discussion \\ Synthesis and Characterization}

In this work, three kinds of QDs (CdSe, $\mathrm{CdSe} / \mathrm{ZnS}$, and $\mathrm{CdSe} / \mathrm{CdS}$ ) were prepared using an organic phase synthesis method. And four kinds of amino acid-polyamine-morpholine derivatives, L-Cysteine-2-amino-3-mercapto-N-(3-morpholinopropyl) propanamide (L-Cys-MPA), L-Cysteine- $\mathrm{N}^{1}$-(3-morpholinopropyl) propane-1,3-diamine (L-Cys-MPPDA), L-Cysteine- $\mathrm{N}^{1}$-(4-morpholinobutyl)
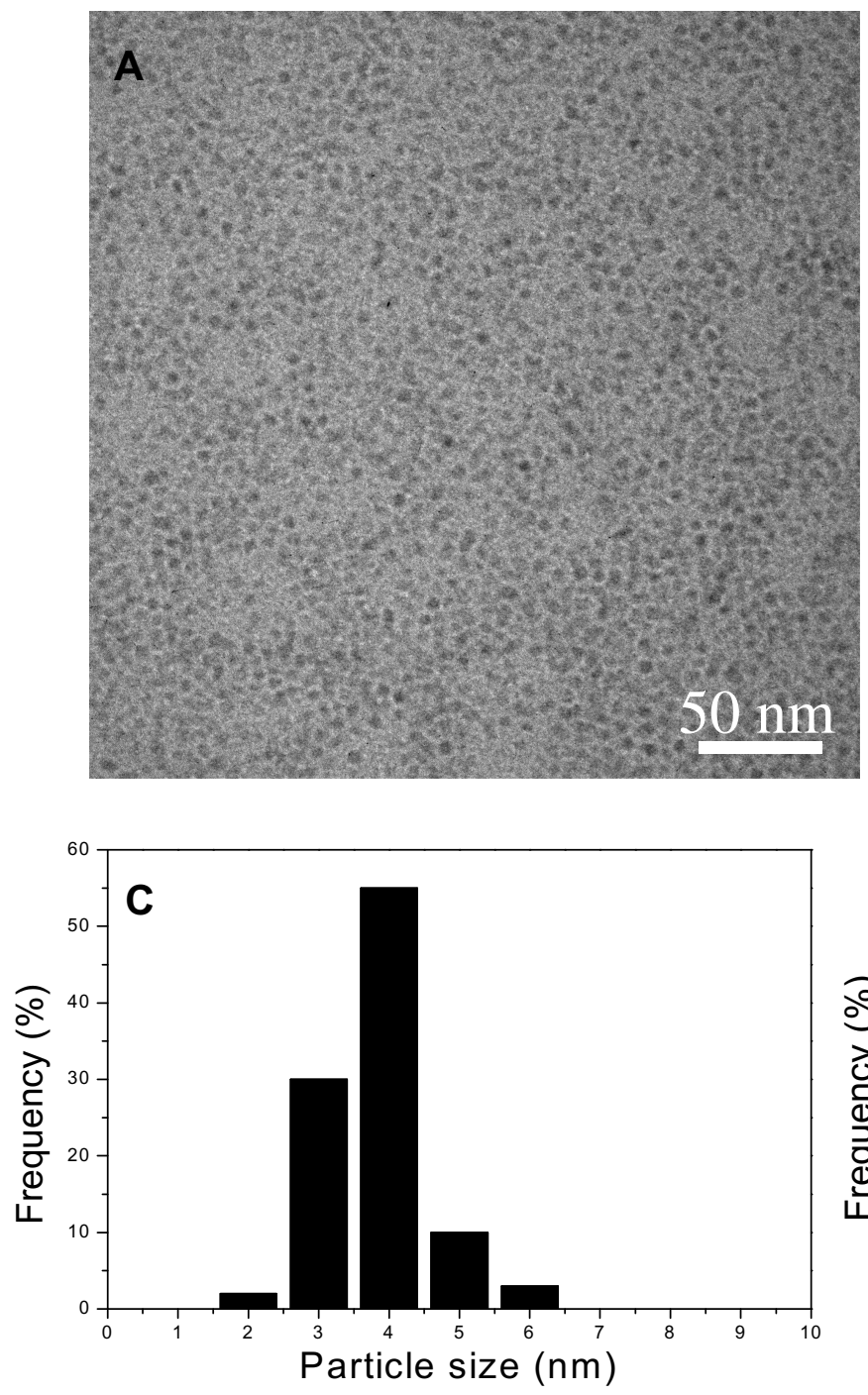

Figure I TEM images and size distribution of CdSe/ZnS QDs (A, C) and CdSe/ZnS@L-Cys-MPPDA QDs (B, D) (scale bars = 50 nm).
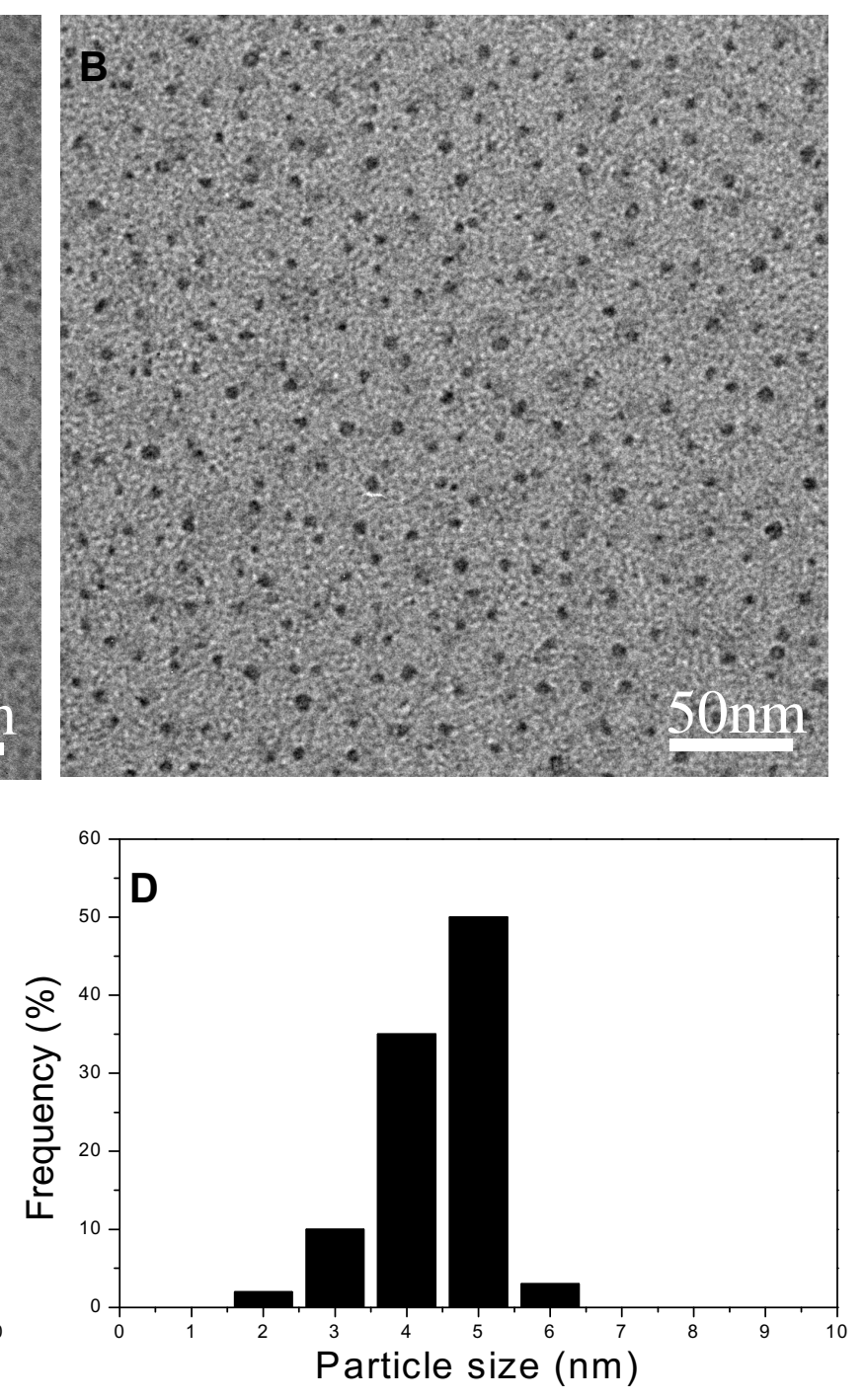

butane-1,4-diamine (L-Cys-MBBDA), and L-Cysteine- $\mathrm{N}^{1}$ (3-aminopropyl)- $\mathrm{N}^{3}$-(3-morpholinopropyl) propane-1,3-diamine (L-Cys-AMPDA), were connected to the surface of QDs. Synthesized ligands were characterised by ESI-MS, ${ }^{1} \mathrm{H}$ NMR spectroscopy, and ${ }^{13} \mathrm{C}$ NMR spectroscopy. In addition, we characterized the size and dispersion of original QDs and cysteine-polyamine-morpholine-modified QDs using TEM. As shown in Figure 1, the cysteine-polyamine-morpholine-modified QDs maintained uniform dispersion and a spherical shape when suspended in PBS. Namely, the modified QDs had good water solubility and dispersed evenly.

QDs had improved better optical properties when measured using UV/Vis spectra and fluorescence spectroscopy. Figure 2 presents absorption spectra of original QDs and the cysteine-polyamine-morpholine modified QDs, where 

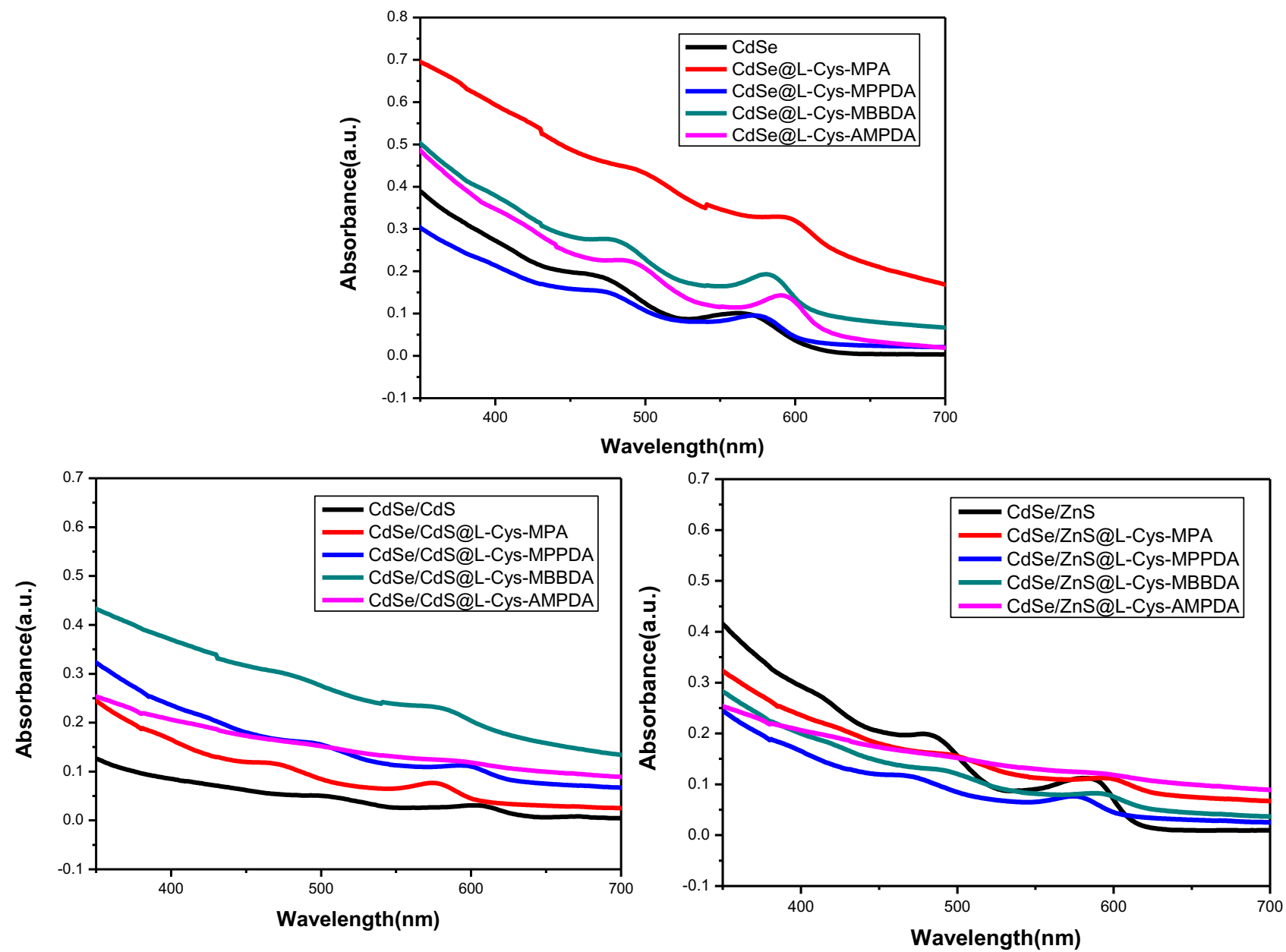

Figure 2 UV-Vis spectra of original QDs and cysteine-polyamine-morpholine-modified QDs.

it is clear the UV-Vis absorption spectra of QDs had absorption properties typical of $\mathrm{CdSe}, \mathrm{CdSe} / \mathrm{CdS}$, and CdSe/ZnS QDs. The shell would not affect peak position of the absorption spectra of QDs due to the high energy band gap of $\mathrm{ZnS}$ in comparison to that of either $\mathrm{CdS}$ or CdSe ${ }^{58}$ Absorbance peak of modified QDs has a slight red-shift relative to that of the original QD nanoparticles. Therefore, it is likely that the cysteine-polyaminemorpholine has been successfully incorporated into QD nanoparticles.

The original QDs and cysteine-polyamine-morpholine -modified QDs were further characterized by fluorescence spectroscopy. As shown in Figure 3, the fluorescence peak of cysteine-polyamine-morpholine modified QDs exhibited a slight red-shifted emission spectra when compared with that of corresponding QDs, suggesting that the elicited wavelengths arose due to recombination of cysteine-polyamine-morpholine derivatives on the surface of QDs. Bands of fluorescence of modified QDs were broad and significantly more intense when compared to that of original QDs. Differences in bands of fluorescence among QDs were likely due to recombination of cysteine-polyamine-morpholine derivatives on their surface.

\section{Cell Cytotoxicity Assay}

In order to explore the cell toxicity of original QDs, amino acid-polyamine-morpholine-modified QDs, HeLa, SMMC-7721 and HepG2 cells were treated with different concentrations of samples for $48 \mathrm{hrs}$. Cytotoxicity was measured using the MTT assay. The $\mathrm{IC}_{50}$ values of original QDs and cysteine-polyamine-morpholine-modified QDs in HeLa, SMMC-7721 and HepG2 cells are presented in Table 1. Calculated $\mathrm{IC}_{50}$ values demonstrate that original QDs have greater cytotoxicity when compared with cysteine-polyamine-morpholine-modified 

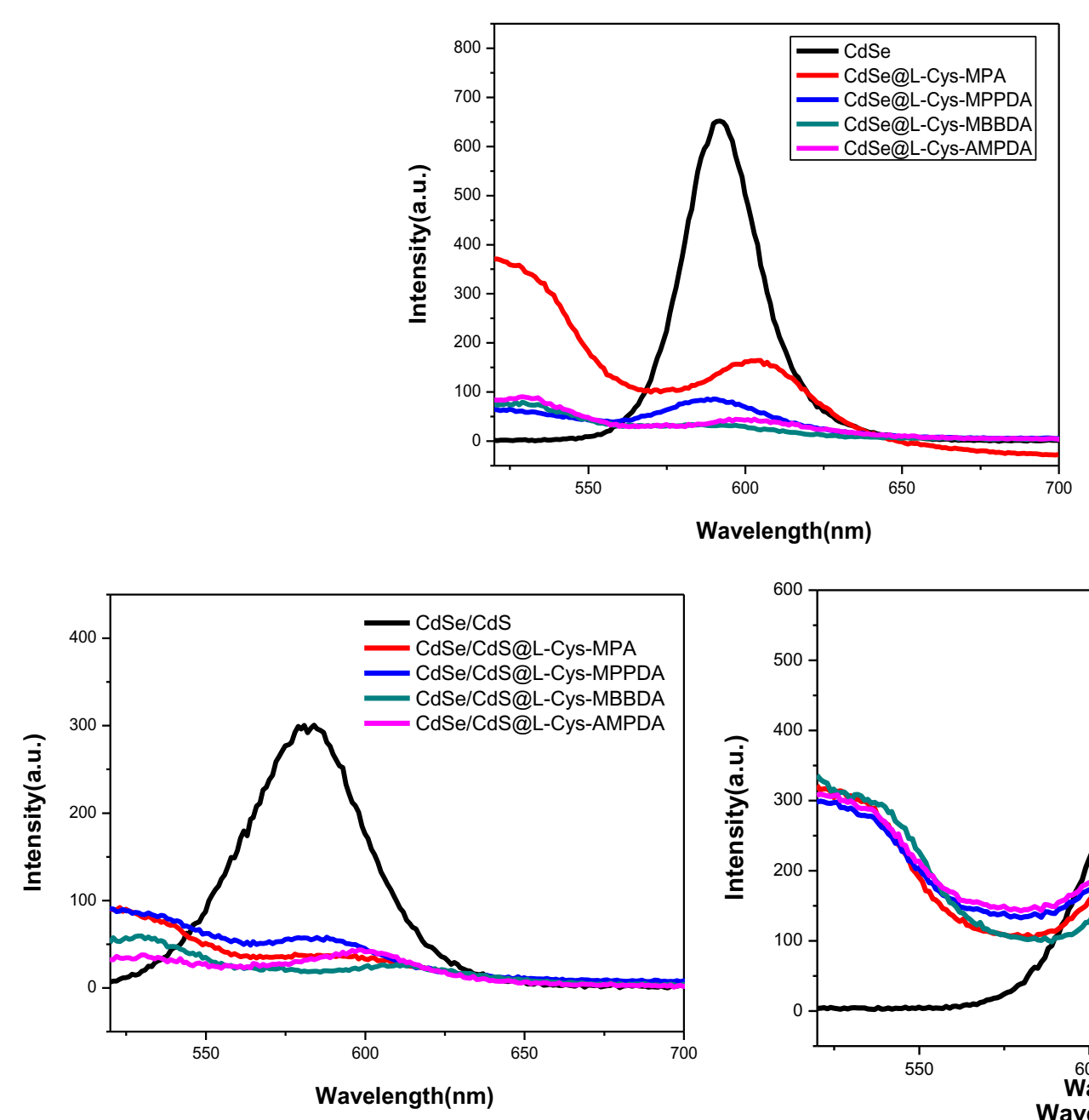

Figure 3 Fluorescence spectra of original QDs and cysteine-polyamine-morpholine-modified QDs.

QDs. Because CdSe QDs may slowly release the toxic $\mathrm{Cd}^{\mathrm{II}}$ ions into solution, it is expected that particles would be inert for a short period of time during in vitro application. The release of $\mathrm{Cd}^{\mathrm{II}}$ from the particle surface can be reduced using core/shell particles or coating of the particles with biomolecules or a polymer. Results of this study indicate that the developed cysteine-polyaminemorpholine-modified QDs reduce release of toxic $\mathrm{Cd}^{\mathrm{II}}$ ions from QDs.

\section{Fluorescent Labeling of Cells}

The unique optical properties of QDs make them useful as biological fluorescent probes. ${ }^{59,60}$ Laser scanning confocal microscopy was used to study fluorescence intensity of cysteine-polyamine-morpholine-modified QDs at different concentrations across time. Since CdSe/ZnS@L-CysMPPDA QDs showed good optical properties and minimal toxicity in this work, they were used as a representative QDs in subsequent experiments. Figure 4 presents changes in fluorescence intensity of CdSe/ZnS@L-Cys-MPPDA QDs at different concentrations in cells. As concentration increased, more CdSe/ZnS@L-Cys-MPPDA QDs entered the cell and a concomitant increase in fluorescence intensity was observed. Furthermore, it was observed that QDs selectively accumulated in the cytoplasm of cells. Accumulation of CdSe/ZnS@L-Cys-MPPDA QDs (200 $\mu \mathrm{g} / \mathrm{mL}$ ) in HeLa cells over differing incubation periods was monitored (Figure 5). As presented in Figure 5, fluorescence intensity of QDs in cells gradually increased with incubation time and reached a plateau in the cytoplasm after 6 hrs. Remarkably, the fluorescence intensity of QDs in cells did not decrease following $24 \mathrm{hrs}$ incubation. Thus, the fluorescence intensity of CdSe/ZnS@L-CysMPPDA QDs treated cells increased with increasing 
Table I IC 50 Values of Modified and Unmodified QDs to HeLa, SMMC-772I and HepG2 Cells

\begin{tabular}{|l|l|l|l|}
\hline \multirow{2}{*}{ Compounds } & \multicolumn{3}{l}{ IC 50 ( $\mu$ g/mL) } \\
\cline { 2 - 4 } & HeLa & SMMC-772I & HepG2 \\
\hline CdSe@L-Cys-MPA & $798.2 \pm 1.9$ & $767.9 \pm 2.7$ & $703.1 \pm 3.2$ \\
CdSe/ZnS@L-Cys-MPA & $816.5 \pm 2.5$ & $775.6 \pm 2.9$ & $823.8 \pm 2.0$ \\
CdSe/CdS@L-Cys-MPA & $820.3 \pm 4.3$ & $817.0 \pm 3.5$ & $757.4 \pm 2.9$ \\
CdSe@L-Cys-MPPDA & $779.0 \pm 1.8$ & $796.1 \pm 2.4$ & $775.0 \pm 2.3$ \\
CdSe/ZnS@L-Cys-MPPDA & $830.7 \pm 3.2$ & $858.2 \pm 2.8$ & $869.1 \pm 1.8$ \\
CdSe/CdS@L-Cys-MPPDA & $798.4 \pm 3.7$ & $803.6 \pm 1.2$ & $827.8 \pm 2.1$ \\
CdSe@L-Cys-MBBDA & $512.9 \pm 2.5$ & $686.9 \pm 0.9$ & $700.6 \pm 1.4$ \\
CdSe/ZnS@L-Cys-MBBDA & $771.7 \pm 4.0$ & $798.0 \pm 3.1$ & $815.9 \pm 3.3$ \\
CdSe/CdS@L-Cys-MBBDA & $657.3 \pm 1.6$ & $754.6 \pm 2.6$ & $768.0 \pm 2.0$ \\
CdSe@L-Cys-AMPDA & $767.5 \pm 3.0$ & $779.0 \pm 2.3$ & $796.2 \pm 2.6$ \\
CdSe/ZnS@L-Cys-AMPDA & $823.4 \pm 1.1$ & $812.6 \pm 0.8$ & $826.9 \pm 2.4$ \\
CdSe/CdS@L-Cys-AMPDA & $779.8 \pm 2.7$ & $795.2 \pm 1.8$ & $814.0 \pm 1.3$ \\
CdSe & $15.5 \pm 2.5$ & $13.9 \pm 3.1$ & $14.5 \pm 3.4$ \\
CdSe/ZnS & $18.4 \pm 2.2$ & $18.2 \pm 1.9$ & $18.7 \pm 2.9$ \\
CdSe/CdS & $16.2 \pm 3.1$ & $15.4 \pm 2.7$ & $16.8 \pm 2.8$ \\
\hline
\end{tabular}

concentrations and incubation times. So the cysteinepolyamine-morpholine-modified QDs can act as potential fluorescent probes for cells.

To confirm the cell selectivity of the QDs in vitro, HT29, HepG2, SMMC-7721 and HeLa cells were incubated with CdSe/ZnS@L-Cys-MPPDA QDs. After incubation for 6 hrs with QDs, the cells were washed. And the images of cells were collected under CLSM. As shown in Figure 6, the fluorescence intensity of CdSe/ZnS@L-Cys-MPPDA QDs in SMMC-7, HepG2, and HT-29 cells was weak and little to no fluorescence was observed. However, the fluorescence intensity of CdSe/ZnS@L-Cys-MPPDA QDs in $\mathrm{HeLa}$ cells was strong. These results provide strong evidence to suggest CdSe/ZnS@L-Cys-MPPDA QDs have strong HeLa cells targeting ability.

In addition, labeling of subcellular compartments by QDs was of particular importance. To further study targeting and localization of modified QDs in cells, we stained HeLa cells with the lysosome green fluorescent probe LysoTracker Green DND-26, and observed distribution of QDs in HeLa cells using laser confocal microscopy. As can be seen from Figure 7, the fluorescence of $\mathrm{CdSe} /$ ZnS@L-Cys-MPPDA QDs demonstrated complete colocalization with lysosomes in HeLa cells. Evaluation of the staining patterns and co-localization demonstrated that CdSe/ZnS@L-Cys-MPPDA QDs remained intact following uptake and had a perinuclear distribution; therefore, these results suggest that QDs are predominantly confined within lysosomes. This evidence indicates that nearly all cysteine-polyamine-morpholine-modified QDs were transported inside lysosomes without release to the cytoplasm or nucleus. Lysosome targeting of modified QDs may be attributed to the morpholine group of ligand cysteinepolyamine-morpholine.

\section{Conclusion}

In conclusion, a new class of fluorescence probes, L-cysteine-polyamine-morpholine-modified QDs was synthesized in this work. These modified QDs had good water solubility and dispersed evenly. And the modified QDs had lower cytotoxicity to cells in vitro when
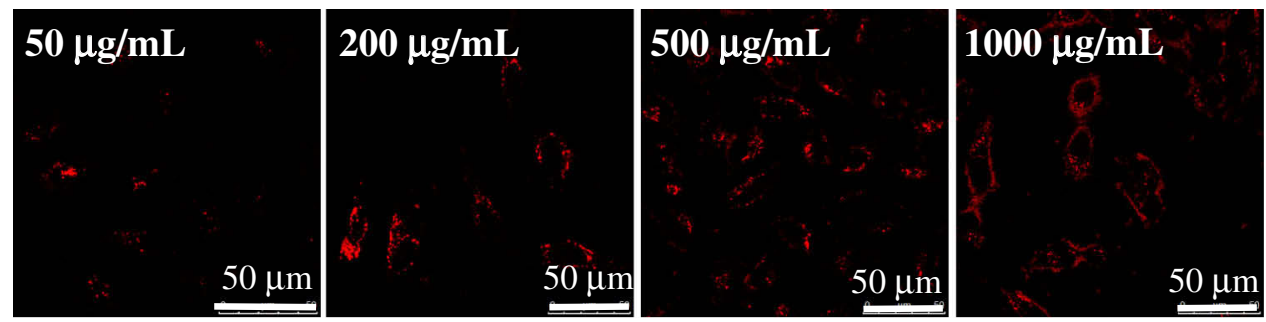

Figure 4 Confocal images of HeLa cells treated with CdSe/ZnS@L-Cys-MPPDA for 6 hrs at $37^{\circ} \mathrm{C}$ with different concentrations.
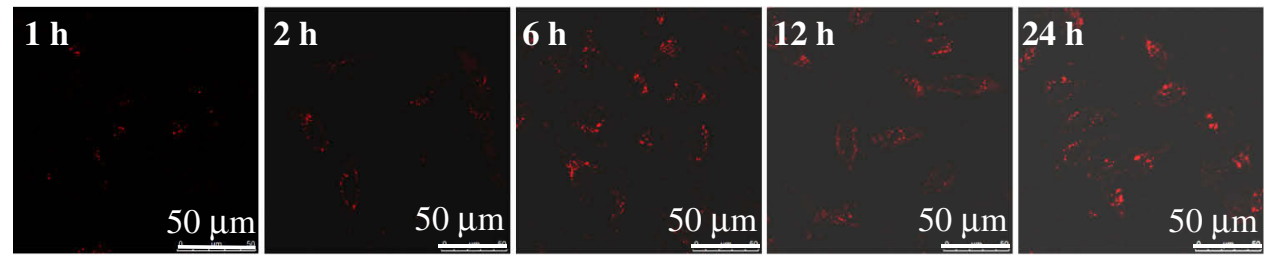

Figure 5 Confocal images of HeLa cells treated with CdSe/ZnS@L-Cys-MPPDA ( $200 \mu \mathrm{g} / \mathrm{mL})$ at $37^{\circ} \mathrm{C}$ in the medium at different time. 


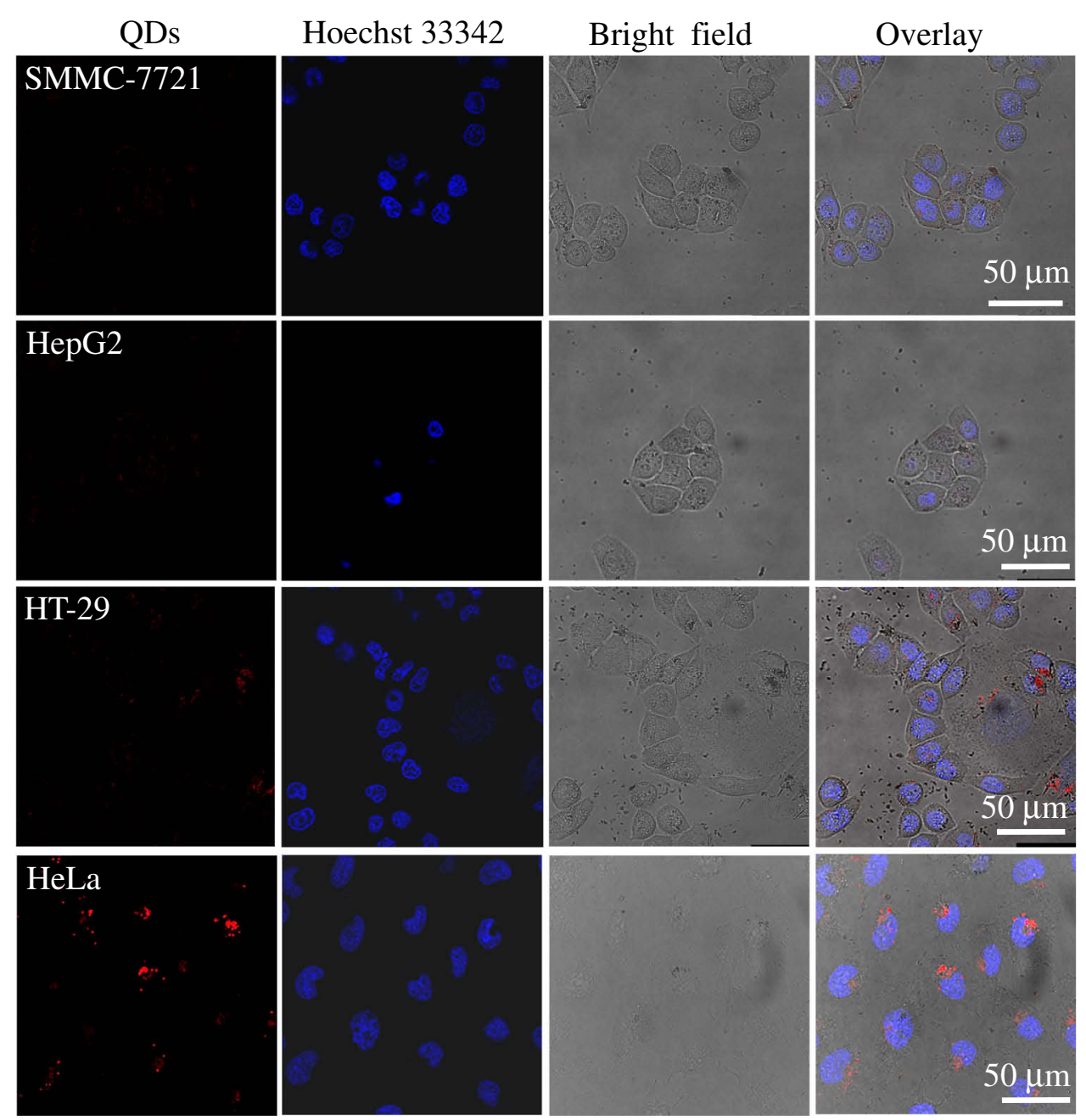

Figure 6 Confocal images of different cells treated with CdSe/ZnS@L-Cys-MPPDA $(200 \mu \mathrm{g} / \mathrm{mL})$ for 6 hrs at $37^{\circ} \mathrm{C}$.

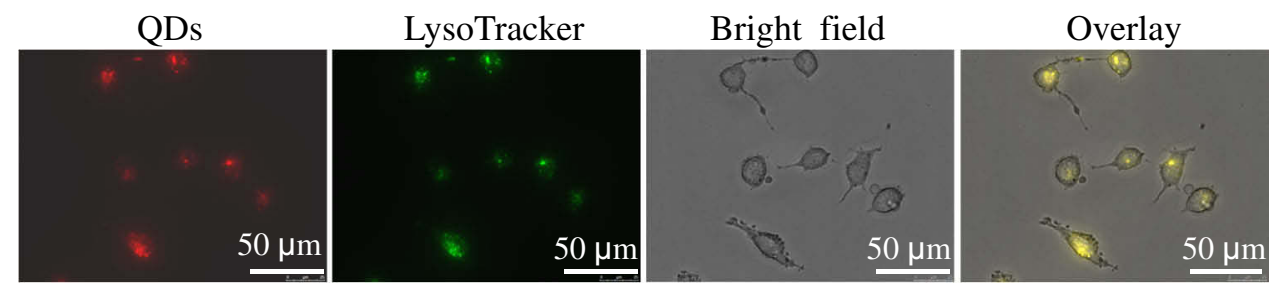

Figure 7 The CdSe/ZnS@L-Cys-MPPDA QDs display co-localization with lysosomes in HeLa cells.

compared to unmodified QDs. In addition, modified QDs had strong fluorescence intensity in HeLa cells and effectively targeted lysosome of HeLa cells. Therefore, modified QDs can efficiently enter cells and could be used as lysosome-targetable fluorescent probes.

\section{Acknowledgment}

This work was supported by National Natural Science Foundation of China (21501044), Program for
Innovative Research Talents from the University of Henan Province (18HASTIT049), Foundation of Science and Technology Department of Henan Province (182102410075), First-class Discipline Cultivation Project of Henan University-innovation Team Cultivation (2018YLTD10), Major Cultivation Project of First-class Discipline of Henan University (2019YLZDJL09), and Special Professor Project of Henan University. 


\section{Author Contributions}

All authors contributed to data analysis, drafting or revising the article, gave final approval of the version to be published, and agree to be accountable for all aspects of the work.

\section{Disclosure}

The authors report no conflicts of interest in this work.

\section{References}

1. Pidluzhna A, Ivaniuk K, Stakhira P, et al. Multi-channel electroluminescence of $\mathrm{CdTe} / \mathrm{CdS}$ core-shell quantum dots implemented into a QLED device. Dyes Pigm. 2019;162:647-653. doi:10.1016/j. dyepig.2018.10.074

2. McAdams SG, Lewis DJ, McNaughter PD, et al. High magnetic relaxivity in a fluorescent $\mathrm{CdSe} / \mathrm{CdS} / \mathrm{ZnS}$ quantum dot functionalized with MRI contrast molecules. Chem Commun. (Camb). 2017;53 (76):10500-10503. doi:10.1039/C7CC05537D

3. Zhao M-X, Zeng E-Z, Zhu B-J. The biological applications of inorganic nanoparticle drug carriers. ChemNanoMat. 2015;1:82-91. doi:10.1002/cnma.201500036

4. Yang HY, Fu Y, Jang MS, et al. CdSe@ZnS/ZnS quantum dots loaded in polymeric micelles as a $\mathrm{pH}$-triggerable targeting fluorescence imaging probe for detecting cerebral ischemic area. Colloids Surf B Biointerfaces. 2017;155:497-506. doi:10.1016/j.colsurfb.20 17.04.054

5. Li Q, Peng H, Wang J, Wang Y, Guo F. Coexpression of CdSe and $\mathrm{CdSe} / \mathrm{CdS}$ quantum dots in live cells using molecular hyperspectral imaging technology. J Biomed Opt. 2015;20(11):110504. doi:10.11 17/1.JBO.20.11.110504

6. Oliveira E, Santos HM, Jorge S, et al. Sustainable synthesis of luminescent $\mathrm{CdTe}$ quantum dots coated with modified silica mesoporous nanoparticles: towards new protein scavengers and smart drug delivery carrier. Dyes Pigm. 2019;161:360-369. doi:10.1016/j. talanta.2018.02.063

7. Tan L, Ge J, Jiao M, Jie G, Niu S. Amplified electrochemiluminescence detection of DNA based on novel quantum dots signal probe by multiple cycling amplification strategy. Talanta. 2018;183:10 8-113. doi:10.1016/j.talanta.2018.02.063

8. Dong X, Ren J, Li T, Wang Y. Synthesis, characterization and application of red-emitting CuInS2/ZnS quantum dots for warm white light-emitting diodes. Dyes Pigm. 2019;165:273-278. doi:10. 1016/j.dyepig.2019.02.035

9. Zhao M-X, Zhu B-J, Yao W-J, Chen D-F, Wang C. The delivery of doxorubicin of multifunctional $\beta$-cyclodextrin-modified $\mathrm{CdSe} / \mathrm{ZnS}$ quantum dots for bioactivity and nano-probing. Chem Biol Drug Des. 2018;91:285-293. doi:10.1111/cbdd.13080

10. Kumari A, Sharma A, Malairaman U, Singh RR. Proficient surface modification of CdSe quantum dots for highly luminescent and biocompatible probes for bioimaging: a comparative experimental investigation J Lumin. 2018;199:174-182. doi:10.1016/j.jlumin.2018.03.032

11. Bach LG, Nguyen TD, Thuong NT, Van HTT, Lim KT. Glutathione capped CdSe quantum dots: synthesis, characterization, morphology, and application as a sensor for toxic metal ions. $J$ Nanosci Nanotechnol. 2019;19(2):1192-1195. doi:10.1166/jnn.2019.15924

12. Zhao M-X, Zhu B-J, Yao W-J, Chen D-F. Therapeutic effect of quantum dots for cancer treatment. RSC Adv. 2016;6:113791-113795. doi:10.1039/C6RA24063A

13. Swart I, Liljeroth P, Vanmaekelbergh D. Scanning probe microscopy and spectroscopy of colloidal semiconductor nanocrystals and assembled structures. Chem Rev. 2016;116(18):11181-11219. doi:10. 1021/acs.chemrev.5b00678
14. Lim SJ, Ma L, Schleife A, Smith AM. Quantum dot surface engineering: toward inert fluorophores with compact size and bright, stable emission. Coord Chem Rev. 2016;320-321:216-237. doi:10. 1016/j.ccr.2016.03.012

15. Shuang W, Wang XB, Wang G, et al. Facile and controlled synthesis of stable water-soluble cupric sulfide quantum dots for significantly inhibiting the proliferation of cancer cells. J Mater Chem B. 2015;3 (27):5603-5607. doi:10.1039/C5TB00960J

16. Zhao M-X, Zeng E-Z. Application of functional quantum dot nanoparticles as fluorescence probes in cell labeling and tumor diagnostic imaging. Nanoscale Res Lett. 2015;10:171. doi:10.1186/s11671-0150873-8

17. Wang $\mathrm{C}, \mathrm{Gao} X, \mathrm{Su} X$. In vitro and in vivo imaging with quantum dots. Anal Bioanal Chem. 2010;397(4):1397-1415. doi:10.1007/ s00216-010-3481-6

18. Bilan R, Nabiev I, Sukhanova A. Quantum dot-based nanotools for bioimaging, diagnostics, and drug delivery. Chembiochem. 2016;17 (22):2103-2114. doi:10.1002/cbic.v17.22

19. Soenen SJ, Parak WJ, Rejman J, Manshian B. (Intra) cellular stability of inorganic nanoparticles: effects on cytotoxicity, particle functionality, and biomedical applications. Chem Rev. 2015;115(5):2109-21 35. doi:10.1021/cr400714j

20. Han X, Lei J, Chen K, et al. Cytotoxicity of CdTe quantum dots with different surface coatings against yeast Saccharomyces cerevisiae. Ecotoxicol Environ Saf. 2019;174:467-474. doi:10.1016/j.ecoenv. 2019.03.013

21. Zhao M-X, Zeng E-Z, Li Y, Wang C-J. A study on effects of naphthalimide derivative-capped quantum dots on the cellular internalization, proliferation, and apoptosis ability. $J$ Mater Chem $B$. 2014;2:7351-7359. doi:10.1039/C4TB01048E

22. Liang $X$, Tang M. Research advances on cytotoxicity of cadmium-containing quantum dots. J Nanosci Nanotechnol. 2019;19: 5375-5387. doi:10.1166/jnn.2019.16783

23. Mirnajafizadeh F, Ramsey D, McAlpine S, Wang F, Stride JA. Nanoparticles for bioapplications: study of the cytotoxicity of water dispersible $\mathrm{CdSe}(\mathrm{S})$ and $\mathrm{CdSe}(\mathrm{S}) / \mathrm{ZnO}$ quantum dots. Nanomaterials (Basel). 2019;9(3):E465. doi:10.3390/nano9030465

24. Yukawa $\mathrm{H}$, Baba $\mathrm{Y}$. In vivo fluorescence imaging and the diagnosis of stem cells using quantum dots for regenerative medicine. Anal Chem. 2017;89(5):2671-2681. doi:10.1021/acs.analchem.6b0 4763

25. Guo J-W, Wu Y-H, Wei P-L, Huang Y-J, Chen J-K. Immobilization of antibody conjugated $\mathrm{ZnS}$ quantum dots onto poly(2,6-dimethyl1,4-phenylene oxide) nanofibers with poly ( $\mathrm{N}$-isopropylacrylamide) grafts as reversibly fluorescence immunoassay. Dyes Pigm. 2018;159:198-208. doi:10.1016/j.dyepig.2018.05.059

26. Taniguchi S, Sandiford L, Cooper M, et al. Hydrophobinencapsulated quantum dots. ACS Appl Mater Interfaces. 2016;8 (7):4887-4893. doi:10.1021/acsami.5b11354

27. Zhao M-X, Li Y, Zeng E-Z, Wang C. The application of CdSe quantum dots with multicolor emission as fluorescent probes for cell labeling. Chem Asian J. 2014;9:1349-1355. doi:10.1002/asia. 201301692

28. Suzuki M, Udaka H, Fukuda T. Quantum dot-linked immunosorbent assay (QLISA) using orientation-directed antibodies. J Pharm Biomed Anal. 2017;143:110-115. doi:10.1016/j.jpba.2017.05.014

29. Liu H, Sun Y, Li Z, et al. Lysosome-targeted carbon dots for ratiometric imaging of formaldehyde in living cells. Nanoscale. 2019;11 (17):8458-8463. doi:10.1039/C9NR01678C

30. Li Z, Wang Y, Wang J, Tang Z, Pounds JG, Lin Y. Rapid and sensitive detection of protein biomarker using a portable fluorescence biosensor based on quantum dots and a lateral flow test strip. Anal Chem. 2010;82(16):7008-7014. doi:10.1021/ac101405a

31. Ma Q, Wang C, Su X. Synthesis and application of quantum dot-tagged fluorescent microbeads. J Nanosci Nanotechnol. 2008;8 (3):1138-1149. doi:10.1166/jnn.2008.308 
32. Silva AC, Freschi AP, Rodrigues CM, et al. Biological analysis and imaging applications of $\mathrm{CdSe} / \mathrm{CdSxSe} 1-\mathrm{x} / \mathrm{CdS}$ core-shell magic-sized quantum dot. Nanomedicine. 2016;12(5):1421-1430. doi:10.1016/j. nano.2016.01.001

33. Zhao M-X, Zhu B-J. The research and applications of quantum dots as nano-carriers for targeted drug delivery and cancer therapy. Nanoscale Res Lett. 2016;11:207. doi:10.1186/s11671-016-1394-9

34. Shibu ES, Hamada M, Nakanishi S, Wakida S, Biju V. Photoluminescence of $\mathrm{CdSe}$ and $\mathrm{CdSe} / \mathrm{ZnS}$ quantum dots: modifications for making the invisible visible at ensemble and single-molecule levels. Coord Chem Rev. 2014;263:2-12. doi:10.1016/j.ccr.2013.10.014

35. Wijaya H, Darwan D, Lim KRG, Wang T, Khoo KH, Tan ZK. Largestokes-shifted infrared-emitting InAs-In(Zn) P-ZnSe-ZnS giant-shell quantum dots by one-pot continuous-injection synthesis. Chem Mater. 2019;31(6):2019-2026. doi:10.1021/acs.chemmater.8b05023

36. Higuchi CM, Wang W. Comodulation of cellular polyamines and proliferation: biomarker application to colorectal mucosa. $J$ Cell Biochem. 1995;57(2):256-261. doi:10.1002/(ISSN)1097-4644

37. Bae DH, Lane DJR, Jansson PJ, Richardson DR. The old and new biochemistry of polyamines. Biochim Biophys Acta Gen Subj. 2018;1862(9):2053-2068. doi:10.1016/j.bbagen.2018.06.004

38. Weiger TM, Hermann A. Cell proliferation, potassium channels, polyamines and their interactions: a mini review. Amino Acids. 2014;46(3):681-688. doi:10.1007/s00726-013-1536-7

39. Janne J, Poso H, Raina A. Polyamines in rapid growth and cancer. Biochim Biophys Acta. 1978;473(3-4):241-293. doi:10.1016/0304419x(78)90015-x

40. van Biljon R, Niemand J, van Wyk R, et al. Inducing controlled cell cycle arrest and re-entry during asexual proliferation of Plasmodium falciparum malaria parasites. Sci Rep. 2018;8(1):16581. doi:10.1038/ s41598-018-34964-w

41. König SG, Krämer R. Polyamine-modified near-infrared cyanine dyes for targeting the nuclei and nucleoli of cells. Dyes Pigm. 2017;145:80-94. doi:10.1016/j.dyepig.2017.05.041

42. Frau M, Feo F, Pascale RM. Pleiotropic effects of methionine adenosyltransferases deregulation as determinants of liver cancer progression and prognosis. J Hepatol. 2013;59(4):830-841. doi:10.1016/ j.jhep.2013.04.031

43. Zhang L, Lee HK, Pruess TH, White HS, Bulaj G. Synthesis and applications of polyamine amino acid residues: improving the bioactivity of an analgesic neuropeptide, neurotensin. J Med Chem. 2009;52(6):1514-1517. doi:10.1021/jm801481y

44. Bisceglia JA, Mollo MC, Gruber N, Orelli LR. Polyamines and related nitrogen compounds in the chemotherapy of neglected diseases caused by kinetoplastids. Curr Top Med Chem. 2018;18 (5):321-368. doi:10.2174/1568026618666180427151338

45. Benincasa M, Francescon M, Fregonese $M$, et al. Helical peptide-polyamine and -polyether conjugates as synthetic ionophores. Bioorg Med Chem. 2015;23(23):7386-7393. doi:10.10 16/j.bmc.2015.10.034

46. Huang Z, Gengenbach T, Tian J, Shen W, Garnier G. The role of polyaminoamide-epichlorohydrin (PAE) on antibody longevity in bioactive paper. Colloids Surf B Biointerfaces. 2017;158:197-202. doi:10.1016/j.colsurfb.2017.07.005

International Journal of Nanomedicine

\section{Publish your work in this journal}

The International Journal of Nanomedicine is an international, peerreviewed journal focusing on the application of nanotechnology in diagnostics, therapeutics, and drug delivery systems throughout the biomedical field. This journal is indexed on PubMed Central, MedLine, CAS, SciSearch ${ }^{\circledR}$, Current Contents ${ }^{\circledR} /$ Clinical Medicine,
47. Yang S, Guo W, Sun X. Electrostatic association complex of a polymer capped $\mathrm{CdTe}(\mathrm{S})$ quantum dot and a small molecule dye as a robust ratiometric fluorescence probe of copper ions. Dyes Pigm. 2018;158:114-120. doi:10.1016/j.dyepig.2018.05.031

48. Han $\mathrm{C}$, Li H. Chiral recognition of amino acids based on cyclodextrin-capped quantum dots. Small. 2008;4(9):1344-1350. doi:10.1002/smll.v4:9

49. Zhao M-X, Ji L-N, Mao Z-W. $\beta$-Cyclodextrin/glycyrrhizic acid functionalised quantum dots selectively enter hepatic cells and induce apoptosis. Chem Eur J. 2012;18:1650-1658. doi:10.1002/chem.v18.6

50. Cunha CRA, Oliveira ADPR, Firmino TVC, et al. Biomedical applications of glyconanoparticles based on quantum dots. Biochim Biophys Acta Gen Subj. 2018;1862(3):427-439. doi:10.1016/j. bbagen.2017.11.010

51. Wang Y, Tang M. Dysfunction of various organelles provokes multiple cell death after quantum dot exposure. Int $J$ Nanomedicine. 2018;13:2729-2742. doi:10.2147/IJN

52. Delehanty JB, Blanco-canosa JB, Bradburne CE, et al. Site-specific cellular delivery of quantum dots with chemoselectively-assembled modular peptides. Chem Commun. (Camb). 2013;49(72):7878-7880. doi:10.1039/c3ec42781a

53. Zayed DG, AbdElhamid AS, Freag MS, Elzoghby AO. Hybrid quantum dot-based theranostic nanomedicines for tumor-targeted drug delivery and cancer imaging. Nanomedicine (Lond). 2019;14 (3):225-228. doi:10.2217/nnm-2018-0414

54. Hosseini M, Ganjali MR, Vaezi Z, et al. Selective recognition histidine and tryptophan by enhanced chemiluminescence $\mathrm{ZnSe}$ quantum dots. Sensor Actuat B-Chem. 2015;210:349-354. doi:10.1016/j. snb.2015.01.002

55. Xing R, Chen XD, Zhou YF, et al. Targeting and retention enhancement of quantum dots decorated with amino acids in an invertebrate model organism. Sci Rep. 2016;6:19802. doi:10.1038/srep19802

56. Raju BR, Garcia AMF, Costa ALS, Coutinho PJG, Gonçalves MST. Synthesis of new benzo[a]phenoxazinium probes possessing carboxylic ester, hydroxyl and amino functional groups: photophysical studies in dry ethanol and conjugation with CdTe quantum dots. Dyes Pigm. 2014;110:203-213. doi:10.1016/j.dyepig.2014.04.006

57. Feng W, Feng G. A lysosome-targetable fluorescent probe for imaging ONOO- in living cells and animals. Dyes Pigm. 2019; 164:174-181. doi:10.1016/j.dyepig.2019.01.028

58. Guo W, Li JJ, Wang YA, Peng X. Luminescent CdSe/CdS core/shell nanocrystals in dendron boxes: superior chemical, photochemical and thermal stability. J Am Chem Soc. 2003;125(13):3901-3909. doi:10. $1021 / \mathrm{ja} 028469 \mathrm{c}$

59. Xu H, Li D, Zhao Y, Wang X, Li D, Wang Y. Sodium 4-mercaptophenolate capped $\mathrm{CdSe} / \mathrm{ZnS}$ quantum dots as a fluorescent probe for $\mathrm{pH}$ detection in acidic aqueous media. Luminescence. 2018;33(2):410-416. doi:10.1002/bio.3428

60. Wichner SM, Mann VR, Powers AS, et al. Covalent protein labeling and improved single-molecule optical properties of aqueous $\mathrm{CdSe} /$ CdS quantum dots. ACS Nano. 2017;11(7):6773-6781. doi:10.1021/ acsnano. $7 \mathrm{~b} 01470$

Journal Citation Reports/Science Edition, EMBase, Scopus and the Elsevier Bibliographic databases. The manuscript management system is completely online and includes a very quick and fair peer-review system, which is all easy to use. Visit http://www.dovepress.com/ testimonials.php to read real quotes from published authors. 